\title{
MEASUREMENT OF GENETIC DIVERSITY IN PROGENIES OF SOUR PASSION FRUIT BY WARD-MLM METHODOLOGY: A STRATEGY FOR HETEROTIC GROUP FORMATION
}

\section{Quantificação da diversidade genética em progênies de maracujazeiro-azedo utilizando a metodologia Ward-MLM: estratégia para formação de grupos heteróticos}

\author{
Fernando Higino de Lima e Silva ${ }^{1}$, Alexandre Pio Viana ${ }^{2}$, Rulfe Tavares Ferreira ${ }^{2}$, \\ Jôsie Cloviane de Oliveira Freitas ${ }^{2}$, Jardel Oliveira Santos ${ }^{2}$, Daniele Lima Rodrigues ${ }^{2}$
}

\begin{abstract}
Passion fruit belongs to the family Passifloraceae, and the genus Passiflora is regarded the most economically important. The present study aimed to quantify genetic diversity among progenies of sour passion fruit, in order to define potential heterotic groups, based on morpho-agronomic descriptors, using the Ward-MLM procedure. It is useful for generation advancement in the passion fruit breeding program, via recurrent selection, under development at the Universidade Estadual do Norte Fluminense Darcy Ribeiro (UENF). For such, 81 full-sib progenies belonging to the third recurrent selection cycle $\left(\mathrm{C}_{03}\right)$ were assessed. Twenty-three descriptors were used, five of which were qualitative and 18, quantitative. The quantitative and qualitative variables were analyzed simultaneously using the Ward-MLM procedure for the composition of groups. The likelihood function determined that five was the ideal number of groups. The Ward-MLM classification strategy for morpho-agronomic data analysis allowed the formation of five groups into 26, 5, 15, 16 and 19 progenies. A certain distance was observed for group III, compared to the other groups while groups I, II, IV and V showed approximation. This greater distance of group III compared to the other groups may indicate crosses, aiming at the exploitation of heterosis, for the pyramiding of favorable alleles for traits of interest. The Ward-MLM statistical procedure was a useful tool to detect genetic divergence and group progenies using simultaneously quantitative and qualitative variables.
\end{abstract}

Index Terms: Passiflora edulis Sims., genetic variability, multivariate analysis, characterization of germplasm.

\section{RESUMO}

O maracujazeiro pertence à família Passifloraceae, sendo o gênero Passiflora considerado o de maior importância econômica. O objetivo deste trabalho foi quantificar a diversidade genética entre progênies de maracujazeiro-azedo, a fim de definir possíveis grupos heteróticos, com base em descritores morfo-agronômicos por meio do procedimento Ward-MLM, auxiliando, assim, o avanço de geração no programa de melhoramento genético do maracujazeiro-azedo, via seleção recorrente, em desenvolvimento na Universidade Estadual do Norte Fluminense Darcy Ribeiro (UENF). Para isso, avaliaram-se 81 progênies de irmãos completos pertencentes ao terceiro ciclo de seleção recorrente $\left(\mathrm{C}_{03}\right)$. Foram utilizados 23 descritores, sendo cinco qualitativos e 18 quantitativos. As variáveis quantitativas e qualitativas foram analisadas simultaneamente utilizando o procedimento Ward-MLM para composição dos grupos. Pelo procedimento da função da verossimilhança foi determinado como cinco o número ideal de grupos. A estratégia de classificação Ward-MLM para análise dos dados morfo-agronômicos permitiu a constituição dos cinco grupos em 26, 5, 15, 16 e 19 progênies. Observou-se um distanciamento do grupo III em relação aos demais grupos e a aproximação dos grupos I, II, IV e V. Esse distanciamento do grupo III com os demais grupos pode ser um indicativo de possíveis cruzamentos, visando exploração da heterose, objetivando a piramidização de alelos favoráveis para as características de interesse. O procedimento estatístico Ward-MLM consistiu em uma ferramenta útil para detectar divergência genética e agrupar as progênies utilizando simultaneamente variáveis quantitativas e qualitativas.

Termos para indexação: Passiflora edulis Sims., variabilidade genética, análise multivariada, caracterização do germoplasma.

\section{INTRODUCTION}

Passion fruit belongs to the family Passifloraceae, and the genus Passiflora is regarded the most economically important. Brazil is considered the place of origin of about 139 Passiflora species and the largest center of genetic diversity of the genus (Bernacci et al., 2008). The main cultivated species is Passiflora edulis Sims, also known as sour passion fruit. It accounts for $90 \%$ of the Brazilian orchards, mainly due to its quality, productivity, vigor and juice yield. According to Agrianual (2010) records, Brazil is the largest world producer of sour passion fruit, with a production of about 620,000 tons.

The cultivation of sour passion fruit is explained by its rapid economic return, with revenues distributed in several months each year, during the harvest (Silva; Viana,

${ }^{1}$ Universidade Estadual do Norte Fluminense Darcy/Ribeiro UENF - Av. Alberto Lamego - 2000 - 28013-602 - Campos dos Goytacazes - RJ - Brasil fernandohiginolima@gmail.com

2Universidade Estadual do Norte Fluminense Darcy/Ribeiro UENF - Campos dos Goytacazes - RJ - Brasil

Received in december 12, 2013 and approved in april 10, 2014

Ciênc. Agrotec., Lavras, v.38, n. 3, p.240-246, maio./jun., 2014 
2012). Due to the important economic and social of this culture, it is very important to improve breeding programs that will enable faster development of new cultivars.

The UENF breeding program started in 1998, when the first research targeted the study of genetic diversity in yellow passion fruit accessions collected in the regions Norte and Noroeste Fluminense of the State of Rio de Janeiro, to identify superior genotypes that could be used in a regional improvement program for the crop (Viana et al., 2006).

The second research was to study the genetic parameters, to obtain the progenies thongh crossings between the sour passion fruits selected genotypes, following the Design I. The results of the variance analysis demonstrated large variability to be exploited in the population. The trait number of fruit per plant presented the largest additive genetic variation coefficient, demonstrating that larger gains could be obtained for the trait. In this case the authors indicated the recurrent selection program for study population (Gonçalves et al., 2009a). Currently, the breeding program of the sour passion fruit in UENF is the third cycle of recurrent selection $\left(\mathrm{C}_{03}\right)$.

There is no information in the literature regarding breeding programs in Passiflora through recurrent selection. It is, therefore, a pioneering proposal in terms of research, enabling the generation of large amount of knowledge about the genetic characteristics of culture and adjusting enhancement methods that may be applied to the passion fruit.

The use of measures for the development of productive varieties, with uniform fruits, high content of soluble solids and resistance/tolerance to major pests and diseases may contribute to ensure a steady supply of products to the market and increase the interest from various sectors of agribusiness in the culture. Therefore, passion fruit breeding may contribute substantially to increase productivity and fruit quality.

Studies on genetic diversity are very important in plant breeding because they allow the differentiation of accessions and help in the identification of contrasting genotypes for the performance of promising crosses. They are important tools to identify possible groups with a higher degree of heterosis in future crosses, and to find sources of resistance to diseases.. Melchinger and Gumber (1998) defined a heterotic group "as a group of related or unrelated genotypes from the same or different populations, which display similar combining ability and heterotic response when crossed with genotypes from other genetically distinct germplasm groups. By comparison, the term heterotic pattern refers to a specific pair of two heterotic groups, which express high heterosis and consequently high hybrid performance in their cross."
Despite its importance, few studies have been carried out on the assessment of heterotic groups of sour passion fruit in breeding programs for this culture (Viana et al., 2007).

Genetic variability can be estimated by multivariate analyses based on the differences between accessions. The use of multivariate algorithms aiming to quantify dissimilarity between individuals is considered an essential tool in plant breeding (Gonçalves et al., 2008). The Ward - Modified Location Model (MLM) procedure is a multivariate method proposed by Franco et al. (1998) that works as an excellent strategy for quantifying variability using quantitative and qualitative variables simultaneously.

Therefore, the present study aimed to quantify the genetic diversity among progenies of sour passion fruit at the third cycle of intrapopulation recurrent selection in order to define possible heterotic groups, based on morphological descriptors through the Ward-MLM procedure.

\section{MATERIAL AND METHODS}

A total of 81 full-sib progenies derived from the third cycle $\left(\mathrm{C}_{03}\right)$ of recurrent selection of the passion fruit) were evaluated. The work was conducted at the UENF Experimental Unit, in Itaocara - Ilha Barra do Pomba ( $21^{\circ} 40^{\prime}$ ' south latitude, $42^{\circ} 04^{\prime}$ 'west longitude, and altitude of $76 \mathrm{~m}$ ), Northwestern Rio de Janeiro State. According to Köppen, the climate is Aw, humid tropical, with dry winter and maximum summer rains. The average yearly temperature is around $22.5^{\circ} \mathrm{C}$, around $1.041 \mathrm{~mm}$ rainfall (Fontes et al., 2003).

A vertical cordon was used as the conduction system, with treated 2.5-high eucalyptus fence poles, with spacing of 4 meters between them and wire number 12, at the height of $1.80 \mathrm{~m}$ from the ground. The distance between the planting rows was $3.5 \mathrm{~m}$, so as to allow machines to move within the experiment. All cultural practices were performed when needed according to recommendations for the cultivation of passion fruit (Manica, 1981).

The progenies were planted in November 2011. The harvest was conducted from August 2012 to April 2013. All plants received the treatments recommended for the culture, such as plant cultivation, fertilization, irrigation and control of weeds, pests and diseases. The experiment was arranged in a 9x9 square lattice, with five plants per plot.

Assessments were conducted for the characteristics of the following parts of plants: branch, leaf blade and petiole, flower and fruit. Twenty-three descriptors were used, five of which were qualitative and 18, quantitative. Most of them were provided by the Serviço Nacional 
de Proteção de Cultivares (National Service of Cultivar Protection) - SNPC. The following qualitative descriptors were assessed: branch color, sinus depth, position of the nectaries, skin color and pulp color. The following quantitative descriptors were evaluated: length of blade in $\mathrm{mm}$ (CL); width of blade, in $\mathrm{mm}$ (LL); length of petiole, in $\mathrm{mm}(\mathrm{CP})$; flower diameter, in $\mathrm{mm}(\mathrm{DF})$; corona diameter, in $\mathrm{mm}$ (DC); sepal length, in mm (CS); sepal width, in mm (LS); petal length, in mm (CP); petal width, in mm (LP); bract length, in $\mathrm{mm}$ (CB); peduncle length, in $\mathrm{mm}$ (CPD); androgynophore length, in $\mathrm{mm}(\mathrm{CA})$; fruit mass, in grams (MF); longitudinal fruit diameter, in mm (DLF); transverse fruit diameter, in mm (DTF); pulp mass, in grams (MPL); thickness of the skin, in mm (EC); and content of total soluble solids, in ${ }^{\circ}$ Brix (SST). Five observations were conducted for each qualitative and quantitative variable related to branch, leaf blade, petiole and flower, while ten observations were carried out for the variables related to the fruit. A digital caliper, with $0.01 \mathrm{~mm}$ accuracy, was used for metric determinations, while the masses were obtained with the help of an electronic balance, $0.01 \mathrm{~g}$ accuracy.

The quantitative and qualitative variables were analyzed simultaneously by the Ward-MLM procedure to compose the groups of progenies through the CLUSTER procedure and IML of the SAS software system (Sas Institute, 2003). Then, the Gower algorithm was employed (Gower, 1971) to obtain the distance matrix for the use of the Ward grouping method. The Gower index uses qualitative and quantitative data to generate a single dissimilarity index, ranging from 0 to 1 . Dissimilarity was given by:

$$
S_{i j}=\frac{\sum_{K=1}^{p} W_{i j k} S_{i j k}}{\sum_{k=1}^{p} W_{i j k}}
$$

Where $i$ and $\mathrm{j}$ refer to the individuals to be compared for the trait $\mathrm{k} ; p=$ total number of traits; and $\mathrm{S}_{i j}=$ contribution of the variable $\mathrm{k}$ for the total distance. If a variable is qualitative, $S_{i j k}$ assumes the value 1 , when the agreement is positive or negative for the trait $\mathrm{k}$ between the individuals $i$ and $j$. On the other hand, when the variable is quantitative:

$$
S_{i j}=\frac{\left|Y_{i k}-Y_{j k}\right|}{R_{k}}
$$

Where $\mathrm{R}_{k}=$ the amplitude of variation of the variable $\mathrm{k}$, with values ranging between 0 and 1 . The value of $\mathrm{W}_{i j k}$ was used to define the contributions of $\mathrm{S}_{i j k}$ individuals. Thus, when the value of the variable $k$ is missing in one or both individuals, $\mathrm{W}_{i j k}=0$, or, otherwise, it is equal to a 1 .

The optimal number of groups was defined according to the pseudo-F and pseudo- $\mathrm{t}^{2}$ criteria, combined with the likelihood profile, in association with the likelihood ratio test. Then, the logarithm graph of the maximized likelihood function was obtained, according to the MLM method, for different likely numbers of groups. The best number of groups for analysis was defined according to the likelihood peaks for the different numbers of groups formed by the graph. Finally, the full MLM analysis was performed for the number of groups (g) defined, describing the classification results, with a description table of the groups formed, while the canonical analysis was conducted for the quantitative variables, for which it was used the file canfile obtained by the SAS (Sas Institute, 2003) software system, containing the canonical coordinates for observations.

\section{RESULTS AND DISCUSSION}

The likelihood function procedure determined that five was the ideal number of groups. This optimal number was found where higher increment in logarithmic function was observed, and the fifth group presented the highest absolute value. According to Gonçalves et al. (2009b) and Barbé et al. (2010), the analysis of the likelihood function can define more precise criteria in group formation, resulting in the determination of less subjective groups. The Ward-MLM classification strategy for data analysis allowed the morphological constitution of the five groups in 26, 5, 15, 16 and 19 progenies (Table 1). At this point, it is possible to observe that these groups can be allocated as heterotic groups for the progenies assessed, since this information can be used in association with selection indices, and priority is given to the cross and recombination of superior and more divergent progenies. In a population of 138 individuals of $P$. guajava L., from the UENF breeding program, Campos et al., (2013) observed that the largest increase in the probability function was achieved when five groups were considered.

Regarding the qualitative traits assessed in the branch and leaf blade (Table 1), it was possible to observe that, for the color of the branch, purplish-green prevailed, with $98.75 \%$, while purple obtained only $1.25 \%$ in the progenies evaluated. For this variable, the groups I, II, III and IV showed 100\% purplish- 
green, while group V showed $5.20 \%$ for purple color. For the variable sinus depth, a ratio of $1.25 \%$ for the average depth and $98.75 \%$ for deep was observed for the progenies under study. Groups I, II, III and V presented $100 \%$ deep type sinus, while group IV showed $7 \%$ of the shallow type depth. For the variable position of nectaries, all groups showed nectaries positioned adjacent to the leaf blade. Although these variables do not arise economic interest, knowledge of these traits is fundamental in plant breeding programs, since they provide subsidies for better characterization and subsequent conservation of the species.

Regarding fruit skin, groups II, III, IV and V showed progenies with fruit skin color $100 \%$ yellow, while group I presented progenies with approximately $4 \%$ of the color purplish-yellow for fruit skin. The use of skin color as a descriptor of passion fruit intends to distinguish yellow from purple passion fruit. However, this distinction is irrelevant nowadays, since fruit external color is a complex inherited trait, and many intermediate colors can be observed (Bernacci et al., 2008).

Pulp color showed the greatest variation among progenies within groups, for the qualitative descriptors presented. For the progenies assessed, $65 \%$ showed the color gold; $31.25 \%$, yellow; $2.5 \%$, light orange; and $1.25 \%$, light orange. It is important to study this variable to select progenies targeting both fresh consumption and industrial processing.

The quantitative descriptors revealed wide phenotypic variation among the progenies assessed (Table 2). For the quantitative descriptors related to leaf blade and petiole, it was observed amplitude ranging from 145.46 to $191.05 \mathrm{~mm}$ for CL; 175.02 to $253.65 \mathrm{~mm}$ for LL; and from 45.72 to $80.92 \mathrm{~mm}$ for CPE. Economically, the analysis of these variables isolated is not significant for the study, but it provides useful information for the characterization and subsequent conservation of the species.

For the quantitative descriptors evaluated in the floral part, it was observed that group IV gathered the progenies of greatest value for most traits. CA stands out among the variables evaluated. It showed amplitude between 10.09 and $13.03 \mathrm{~mm}$ in the progenies assessed. CA was assessed because it is directly related to pollination, which in turn is related to production.

Table 1 - Variables and number of progenies per group of qualitative traits in each of the five groups (G1, G2, G3 , G4 and G5 ) formed by the Ward-MLM strategy.

\begin{tabular}{|c|c|c|c|c|c|}
\hline \multirow{2}{*}{ Variables } & \multicolumn{5}{|c|}{ Groups } \\
\hline & G1 (26) & G2 (5) & G3 (15) & G4 (16) & G5 (19) \\
\hline \multicolumn{6}{|l|}{ Color of the branch } \\
\hline Purplish green2 & 26 & 5 & 15 & 15 & 18 \\
\hline Purple & - & - & - & - & 1 \\
\hline \multicolumn{6}{|l|}{ Depth of the sinus } \\
\hline Average & - & - & - & 1 & - \\
\hline Deep & 26 & 5 & 15 & 14 & 19 \\
\hline \multicolumn{6}{|l|}{ Position of nectaries } \\
\hline Adjacent to the leaf blade & 26 & 5 & 15 & 15 & 19 \\
\hline \multicolumn{6}{|l|}{ Skin Color } \\
\hline Yellow & 25 & 5 & 15 & 15 & 19 \\
\hline Purplish-Yellow & 1 & - & - & - & - \\
\hline \multicolumn{6}{|l|}{ Pulp Color } \\
\hline Light-Yellow & - & - & - & 1 & - \\
\hline Yellow & 7 & 1 & 5 & 6 & 6 \\
\hline Golden & 17 & 4 & 10 & 8 & 13 \\
\hline Light orange & 2 & - & - & - & - \\
\hline
\end{tabular}


Table 2 - Means of the quantitative variables for each of the five groups formed by the Ward-MLM method and the coefficients of the quantitative variables in the first two canonical variables.

\begin{tabular}{crrrrrrc}
\hline \multirow{2}{*}{ Variables $^{1}$} & \multicolumn{3}{c}{ Groups } & \multicolumn{3}{c}{ CAN } \\
\cline { 2 - 7 } CL & G1(26) & G2(5) & G3(15) & G4(16) & G5(19) & CAN1 & CAN2 \\
LL & 168.50 & 175.68 & 164.49 & 164.04 & 160.55 & 0.01 & 0.46 \\
PE & 222.25 & 239.43 & 209.48 & 201.80 & 200.52 & -0.06 & 0.71 \\
DF & 64.33 & 68.44 & 60.10 & 57.41 & 59.64 & -0.04 & 0.51 \\
DC & 78.52 & 79.20 & 77.95 & 82.40 & 81.26 & 0.32 & -0.31 \\
CS & 65.86 & 67.42 & 66.91 & 71.45 & 68.67 & 0.24 & -0.36 \\
LS & 33.94 & 33.02 & 32.17 & 34.91 & 34.93 & 0.48 & -0.17 \\
CP & 13.10 & 12.55 & 11.99 & 12.95 & 12.86 & 0.29 & 0.12 \\
LP & 32.91 & 32.72 & 32.85 & 36.30 & 34.29 & 0.37 & 0.43 \\
CB & 10.07 & 10.45 & 9.54 & 10.75 & 10.93 & 0.38 & -0.20 \\
CPD & 26.88 & 27.09 & 26.401 & 28.35 & 25.83 & 0.13 & -0.01 \\
CA & 51.23 & 45.55 & 50.07 & 55.46 & 57.33 & 0.17 & -0.29 \\
MF & 12.14 & 11.31 & 11.11 & 11.89 & 11.94 & 0.39 & 0.16 \\
DLF & 187.89 & 210.27 & 149.63 & 220.55 & 172.10 & 0.62 & 0.09 \\
DTF & 85.19 & 92.00 & 77.04 & 100.27 & 84.72 & 0.39 & -0.09 \\
MPL & 79.20 & 81.16 & 71.20 & 80.57 & 76.16 & 0.66 & 0.32 \\
EC & 76.40 & 89.38 & 63.20 & 93.945 & 67.47 & 0.47 & 0.05 \\
SST & 8.20 & 7.74 & 7.98 & 8.25 & 8.07 & 0.06 & -0.02 \\
\hline
\end{tabular}

1/CL: length of blade, in mm; LL: blade width, in mm; CPE: petiole length, in mm; DF: flower diameter, in mm; DC: corona diameter, in mm; CS: length of the sepal, in mm; LS: sepal width, in mm; CP: petal length, in mm; LP: petal width, in mm; CB: bract length, in $\mathrm{mm}$; CPD: peduncle length, in $\mathrm{mm}$; CA: androgynophore length, in mm; MF: fruit mass, in g; DLF: longitudinal diameter of the fruit, in mm; DTF: transverse diameter of the fruit, in mm; MPL: pulp mass, in g; EC: thickness of the skin, in mm; SST: total soluble solids, in ${ }^{\circ}$ Brix.

Regarding the quantitative descriptors evaluated in the fruit, for the variable MF, it was observed amplitude ranging from 94.06 to $292.43 \mathrm{~g}$. Krause et al. (2012) observed average amplitudes from 132.5 to $178.8 \mathrm{~g}$ for this variable, when they assessed the response of five commercial cultivars of sour passion fruit grown in the state of Mato Grosso. The study of this variable is necessary, since the fruits with more mass are also larger and thus more attractive to consumers.

The variables DLF and DTF presented amplitude ranging from 37.87 to $98.75 \mathrm{~mm}$ and from 65.89 to 90.60 $\mathrm{mm}$, respectively. The ratio between these two variables is very significant since it indicates the size of the fruit. The closer the fruit is to 1 , the rounder it is, and this is a desirable trait because the passion fruit is sorted for being marketed according to its diameter (Krause et al., 2012).
For the variable MPL, it was observed amplitude ranging from 29.2 to $151.01 \mathrm{~g}$. The mass of the pulp is one of the most important physical traits because it is the most consumed part of the fruit, and therefore arouses greater commercial interest.

The variable EC showed amplitude ranging from 4.59 to $12.10 \mathrm{~mm}$. Reduced thickness of fruit skin, combined with other desirable traits, is desirable in sour passion fruit breeding programs because genotypes with reduced skin thickness tend to indicate higher amount of pulp. The SST variable presented amplitude ranging from 11.2 to $17.3{ }^{\circ}$ Brix. The determination of SST is one of the alternatives used to evaluate the flavor of fruits and indicate the amount of solids dissolved in the pulp. High levels are desirable for industrial purposes. Medeiros et al. (2009) evaluated sour passion fruit and 
observed for the variables SST and EC, measured in different months, that the average values decreased from an analysis to another. Besides, a significant difference was observed for all of them, which can be ascribed to weather differences.

The greatest distances were observed for the groups III and IV (61.72), and II and III (43.39) (Table 3). The graphical analysis of VC shows that group III presented greater distance, compared to the other groups formed by the Ward-MLM procedure, while groups I, II, IV and V (Figure 1) showed approximation. This distance of the group III from the other groups may indicate crosses, aiming at the exploitation of heterosis for the pyramiding of alleles favorable for the traits of interest. The smallest distances were found between groups I and V (7.54) and I and II (8.22). Vivas et al. (2012) evaluated the resistance of papaya accessions of the heterotic groups 'Formosa' and 'Solo' to blight on leaves and observed the effect of heterosis on all hybrids derived from crosses between the parents of group 'Solo'. This result was due to the greater genetic distance between parents from the group 'Solo', since the manifestation of heterosis is caused by genetic divergence between parents.

In the analysis based on the canonical variables (VC), it was observed that the first two variables accounted for $89.75 \%$, so that $\mathrm{VC} 1$ was responsible for $68.54 \%$ and VC2, for $21.21 \%$ (Figure 1). Therefore, a two-dimensional graph capitalizes a good proportion of the total variability responsible for the total variation. The graphical analysis of VC shows a greater distance of group III, compared to the other groups formed by the Ward-MLM procedure and approximation of groups I, II, IV and V.

Table 3 - Distance between groups formed by the Ward-MLM procedure, proposed by Franco et al . (1998).

\begin{tabular}{ccccc}
\hline Groups & I & II & III & IV \\
\hline II & 8.22 & & & \\
III & 31.26 & 43.38 & & \\
IV & 18.45 & 24.01 & 61.72 & \\
V & 7.54 & 20.09 & 29.15 & 11.70 \\
\hline
\end{tabular}

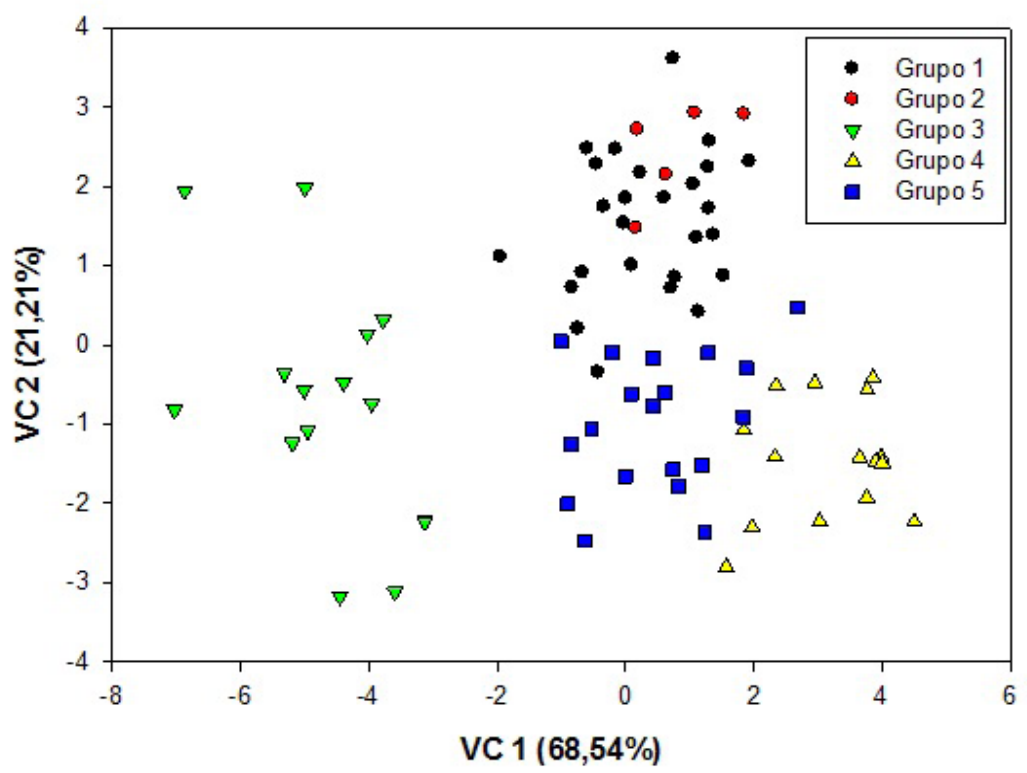

Figure 1 - Graph of the first two canonical variables for the five groups formed by the Ward-MLM analysis. 


\section{CONCLUSIONS}

There is genetic variability among the progenies of passion fruit studied, considering the variables assessed, which enables the composition of heterotic groups as an alternative to direct new crosses and obtain genetic advancement.

The Ward-MLM statistical procedure is a useful tool to detect genetic divergence and cluster accessions using both quantitative and qualitative variables.

This study provided useful information for the determination of the course of the ongoing passion fruit breeding program.

\section{ACKNOWLEDGEMENTS}

To FAPERJ and CNPq, for their financial support to this experiment, and CAPES, for the doctoral scholarship granted to the first author.

\section{REFERENCES}

\section{AGRIANUAL. Anuário estatístico da agricultura} brasileira. São Paulo: FNP, 2010. 520p.

BARBÉ, T.C. et al. Association between advanced generations and genealogy in inbred lines of snap bean by the Ward. Modified Location Model. Euphytica. 173(3):337- 343, 2010.

BERNACCI, L.C. et al. Passiflora edulis Sims: the correct taxonomic way to cite the yellow passion fruit (and of others colors). Revista Brasileira de fruticultura. 30(2):566-576, 2008.

CAMPOS, B.M. et al. Quantificação da divergência genética entre acessos de goiabeira por meio da estratégia Ward-MLM. Revista Brasileira de Fruticultura. 35(2):571-578, 2013.

FRANCO, J. et al. Classifying genetic resources by categorical and continuous variables. Crop Science. 38(6):1688-1696, 1998.

FONTES, P. S. F. et al. Avaliação do estado nutricional e do desenvolvimento da bananeira-prata-anã (Musa spp.) em função da adubação nitrogenada. Revista Brasileira de Fruticultura. 25(1):77-85, 2003.

GONÇALVES, L.S.A. et al. Comparison of multivariate statistical algorithms to cluster tomato heirloom accessions. Genetics and Molecular Research. 7(4):289-1297, 2008.
GONÇALVES, G.M. et al. Genetic parameter estimates in yellow passion fruit based on design I. Brazilian Archives of Biology and Technology. 52(3):87-94, 2009a.

GONÇALVES, L.S.A. et al. Heirloom tomato gene bank: assessing genetic divergence based on morphological, agronomic and molecular data using Ward-modified location model. Genetics and Molecular Research. 8(1):364-374, $2009 \mathrm{~b}$.

GOWER J.C. A general coefficient of similarity and some of its properties. Biometrics. 27(4):857-874, 1971.

KRAUSE, W. et al. Produtividade e qualidade de frutos de cultivares de maracujazeiro-amarelo com ou sem polinização artificial. Pesquisa Agropecuária Brasileira. 47(12):1737-1742, 2012.

MANICA, I. Maracujá: fruticultura tropical. São Paulo: Agronômica Ceres, 1981. 160p

MEDEIROS, S.A.F. et al. Caracterização físico-química de progênies de maracujá-roxo e maracujá-azedo cultivados no Distrito Federal. Revista Brasileira de Fruticultura. 31(2):492-499, 2009.

MELCHINGER, A.E.; GUMBER, R.K. Overview of heterosis and heterotic groups in agronomic crops. In: Lamkey, K.R.; Staub, J.E. Concepts and Breeding of Heterosis in Crop Plants. Madison, WI. 1998. p. 29-44.

\section{SAS INSTITUTE. SAS procedures guide for} computers. Cary, 2003. 965p.

SILVA, M.G. de M.; VIANA, A.P. Alternativas de seleção em população de maracujazeiro-azedo sob seleção recorrente intrapopulacional. Revista brasileira de fruticultura. 34(2):525-531, 2012.

VIANA, A.P et al. Genetic diversity in yellow passion fruit populations. Crop Breeding and Applied Biotechnology.(6):87-94, 2006.

VIANA, A.P. et al. Polinização seletiva em maracujazeiro amarelo (Passiflora edulis f. flavicarpa) monitorada por vetores canônicos. Ciência Rural. 37(5):1627-1633, 2007.

VIVAS, M. et al. Capacidade combinatória e heterose para resistência a pinta-preta em mamoeiro por meio de análise dialélica. Tropical Plant Pathology. 37(5): 326-332, 2012. 